\title{
NATURE CONSERVATION AT THE PROVINCIAL LEVEL IN THE REPUBLIC OF SOUTH AFRICA
}

\section{S S DU PLESSIS}

\author{
Director of Nature Conservation \\ Transvaal Provincial Administration \\ Private Bag X209 \\ Pretoria \\ 0001
}

Before considering the role of the provinces in nature conservation in the Republic of South Africa (RSA) it is necessary to briefly review the responsibilities of other government agencies in this field:

(i) the Department of Planning and the Environment has a coordinating function with regard to environmental conservation and land-use planning;

(ii) the National Parks Board of Trustees is responsible for the establishment and management of national parks;

(iii) the Department of Forestry controls vast natural areas in mountain catchments and also has a system of nature reserves and wilderness areas;

(iv) the Sea Fisheries Division of the Department of Commerce and Industries is responsible for the conservation of marine resources including mammals and birds. The two maritime provinces, however, have jurisdiction over estuaries, while Natal also controls inshore fisheries;

(v) the Weather Bureau of the Department of Transport is responsible for conservation of oceanic islands used as weather stations;

(vi) soil conservation is the responsibility of the Department of Agricultural Technical Services.

In terms of the Financial Relations Act the provincial administrations have been entrusted with the following conservation functions:

(a) the preservation of flora and fauna;

(b) the control of problem animals; and

(c) control of environmental pollution.

While their basic approach is the same, each province has developed its own particular system for dealing with these responsibilities. Their area of jurisdiction covers all land outside national parks and developing territories and it can safely be said that the provinces carry the most 
comprehensive responsibilities for conservation. The functions of a province in the field of preservation of flora and fauna can be divided into three broad categories:

(a) the establishment and management of nature reserves for safeguarding ecosystems and species;

(b) control of the utilization of wildlife by the general public; and

(c) control of problem animals.

\section{Nature reserves}

The system of 70 major provincial reserves covers an area of more than $400000 \mathrm{ha}$, of which more than half is in Natal. They range in size from 47750 ha in the case of Umfolozi Game Reserve to the 101 ha of the Rondevlei Bird Sanctuary.

Although they do not enjoy the status, several of these reserves meet international standards for national parks. The important thing about them is that they are spread all over the country, thus representing a wide variety of habitats. These reserves are put to an infinite variety of uses like safeguarding endangered species of animals or plants, breeding game for distribution, preserving areas of scenic beauty, conservation of ecosystems, education, research, and all compatible forms of outdoor recreation.

In the Cape Province the Divisional Councils have established several reserves with financial assistance from the Administration. A number of municipalities in the RSA also have reserves under their control. Three of the largest nature reserves in the RSA are, however, privately-owned, namely Sabie-Sand, Timbavati and Klaserie, all in the eastern Transvaal lowveld.

\section{Wild animals}

The wildlife on private land outnumber that in national parks and nature reserves, which makes the landowner a key figure in nature conservation. His rôle is complicated by the fact that wildlife is ferae naturae, so he has to share it with his neighbours unless he is prepared to go to the expense of erecting a game-proof fence. The important rôle of the landowner is acknowledged in provincial conservation legislation by giving him maximum possible jurisdiction over game on his land, . especially where it is fenced game-proof. This has encouraged the erection of game-proof fences which has placed severe restrictions on game movements, thereby making them more vulnerable to overpopulation and drought. The sophisticated management needed for fenced game populations is largely lacking amongst owners with the result that in the Transvaal bushveld overpopulation of impala has led to soil erosion. 
With the exception of the Orange Free State, the provinces do not allow public hunting on their reserves. There is, however, a vast potential on private land which is at present not yet exploited. This is mainly due to a lack of interest amongst landowners, who generally do not like the idea of strangers hunting buck on their land. In the Transvaal, the non-owner is turning more and more to bird hunting which appears to be more acceptable to owners than buck hunting.

Whatever the trends may be, the province is responsible for regulating the utilization of game on private land. This can only be achieved with the co-operation of the landowners. Rare and vulnerable species on private land are protected by proclaiming them as protected game, which means that they may not normally be hunted.

Problem animals are animals which do damage to agriculture, but which cannot be successfully controlled by the individual landowner, so that a community effort is needed. The province assists the farming community by doing research on problem animal control, training of hunters and financial support of hunting clubs. The major problem animal is the black-backed jackal. There are, however, pest species like the red-billed quelea and the brown locust which cannot be dealt with by the farming community or on a provincial basis, and is handled by the Department of Agricultural Technical Services.

The province also has to exercise control over the trade in wild animals, including the taking, import, export, keeping in captivity and exhibition of such animals. Trade in live animals or their products has caused the decline of many species, but effective control is difficult to achieve. The Convention on International Trade in Endangered Species of Wild Fauna and Flora will no doubt facilitate such control. The keeping of indigenous seed-eating birds is a popular hobby. Because most species do not breed in captivity they have to be replaced from wild populations, and unless strict control is exercised this hobby could become a threat to these birds. The keeping of animals in captivity is contrary to the ideals of nature conservation and is therefore discouraged. It is, however, very difficult to convince people that they should refrain from keeping these creatures, because to be attracted to wild animals is part of human nature. To separate a person from a longkept pet is a thankless task.

\section{Flora}

The conservation of flora is also of a two-fold nature, namely the establishment of reserves and control over the utilization of species. One of the main objectives of the National Plan for Nature Conservation (under the auspices of NACOR) is to conserve representative examples of all major veld types in the RSA in nature reserves. In addition species reserves for the protection of rare species are necessary.

Control over the utilization of plant species is achieved by proclaiming 
rare and vulnerable species as protected plants which may not be taken without a permit. After cycads became threatened by the activities of illegal collectors in the Transvaal, they were proclaimed as specially protected plants; these may not be possessed, collected, sold, bought, donated, transported, imported or exported without a permit. Such is the market value of these plants that there is still an illegal traffic in spite of the legislation. In an attempt at relieving the pressure on natural populations, the province of Transvaal has embarked on a program of cultivating cycads and selling them to the public.

\section{Inland fisheries}

Freshwater angling is a major form of outdoor recreation in the RSA and fisheries management is aimed mainly at providing for the angler. There is, however, a surplus of non-angling fishes in our major dams which might prove to be harvestable, provided we can devise ways and means of selectively cropping them on an economical basis. There is a growing interest in fish farming which is at present being hampered by marketing problems.

The central problem in management of sport fisheries is public access to angling waters. This problem has been greatly relieved by the policy of the Department of Water Affairs to purchase a strip of land around state dams, our major angling waters.

As man extracts more and more water for his own use, the nature of our rivers as habitat for fishes is being drastically altered, with the result that certain species of fish are treatened with extinction, and steps have to be taken to ensure their survival.

\section{Environmental conservation}

Due to a growing demand for ecological advice on landuse planning and development schemes, the provinces have lately become increasingly involved in environmental conservation matters. They are being consulted on a variety of problems like preservation of open space in municipal areas, the environmental impact of new roads, the planning of big development schemes like Sasol 2 and the Saldanha project, as well as regional guide plans. They also play an active part in the compilation of the National Plan for Nature Conservation. This is a survey of existing conservation areas and areas with potential for nature conservation and outdoor recreation in the future, including special landscapes and outstanding natural phenomena.

The power to legislate on environmental pollution has only recently been delegated to the provinces and they have agreed to start with legislation on the prevention of littering. 


\section{Outdoor recreation}

One of the major objectives of nature reserves is to create opportunities for the public to come into contact with nature. For this purpose visitor facilities have to be provided. This may range from basic facilities like access roads, parking space, picnic spots and campgrounds to fullfledged resorts. An information centre usually figures prominently in any planning of visitor facilities.

Recently the provinces have accepted a significant new responsibility in the field of outdoor recreation when they agreed to take over the control of state dams for the purpose of outdoor recreation and nature conservation from the Department of Water Affairs. Although the emphasis here is on water based recreation like angling, boating and picnicking, there is sufficient state land at some dams to justify the creation of a nature reserve, provided no high-potential agricultural land is involved.

\section{Conclusion}

Within the provincial setup nature conservation is at a bit of a disadvantage in so far as it has to compete for funds with giants like Education, Hospital Services and Roads. It must be accepted, however, that in the wider view nature conservation will always receive low priority.

Dr. Rocco Knobel, Chief Director of National Parks has said that the present generation is the last one that will be able to set aside land for nature conservation. If this is so then the acquisition of more land is the most urgent need in conservation. This can, however, only be done in a meaningful way once land capability classification is introduced into land-use planning.

The provinces are sometimes blamed for a lack of uniformity in nature conservation. In reply it can be said that the various directors have formed an Interprovincial Committee on Nature Conservation which meets twice a year to discuss matters of mutual interest and to try and achieve maximum uniformity. Nature Conservation policy, however, is mostly dictated by local circumstances, so uniformity is only possible in certain matters.

One could also argue that nature conservation suffers because of the various government agencies that are involved, each with its own priorities and preferences. This is a valid point but at the same time one realises that the present setup is an historical fact which is very unlikely to change. The National Committee for Nature Conservation is creating a forum where all these agencies can discuss mutual problems and co-ordinate their efforts in the national interest. 